\title{
Proximate Biological Value (BV) and Protein Efficiency Ratio (PER) of Processed Bush Mango (I. gabonensis) Kernel (PBMK).
}

\author{
Arogba, Sunday S. ${ }^{1} \&$ Matanmisi, Julius A. ${ }^{2}$ \\ ${ }^{1,2}$ Biochemistry Department, Kogi State University, PMB 1008, Anyigba. Nigeria.
}

\begin{abstract}
A novel proximate technique of determining soluble protein equivalents (spe) of Protein Efficiency Ratio (PER) and Biological Value (BV) using Biuret method, is described. The protein quality of processed Bush mango (I. gabonensis) kernel (PBMK) in five feed formulations of Morinda lucida leaf-PBMK was studied. Young goats weighing $5.4 \pm 0.5 \mathrm{~kg}$ were fed for seven weeks with 25, 50, 75, and $100 \%$ PBMK substitutions in the feeds. Results showed that an optimum substitution of 50\% promoted liver growth, overall body weight gain, and improved biological protein status of the animals employed.
\end{abstract}

Keywords:protein quality, proximate indices, soluble protein equivalent, BVspe, PERspe.

\section{Introduction}

Protein nutrition serves to provide the required amino acids for body protein retention, and maintenance. Albumin and other plasma proteins aid the maintenance of blood viscosity, osmolarity, and transportation of lipids and other solutes. Issues of protein quality are of concern especially in third world countries where there is poor quality protein-intake as well as insufficient total caloric intake, which are associated with restricted dietary patterns. Supplementation with other foods becomes a necessity. In contrast to high quality proteins, low quality proteins are deficient in one or more essential amino acid(s) which limit the rate of protein synthesis [1]. The quality of protein is measured by the relative proportion of essential amino acids in a food with that required for good nutrition, using egg or milk protein as standards in most instances [2,3]. Since excess amino acids are not stored for future use, they are rapidly degraded and the nitrogen is excreted as urea and other products through urine, faeces, and desquamating skin.

Popular and measurable indices of protein quality include BV, and PER. Others are Net Protein Utilization (NPU), Chemical Score (CS), and most recently, Protein Digestibility Corrected Amino Acid Score (PDCAAS). The United States of America Food and Nutrition Board estimated from nitrogen balance studies that an average maintenance requirement for an adult was $0.47 \mathrm{~g}$ per $\mathrm{kg}$ body weight per day allowing for excretory losses, $30 \%$ variability in protein metabolism and $25 \%$ variations in biological value of dietary proteins.

Orthodox standard methodologies for protein quality determination have limited relevance when results are interpreted, for instance, BV and CS do not account for digestion and actual absorption of protein unlike PDCAAS and NPU; PER is always measured using young rats and argued to be of little relevance to human physiology; PDCAAS accepts only a highest possible score of 1.0, regardless of the apparent protein quality when a protein contains essential amino acids in excess of human requirements. Furthermore, these orthodox methodologies are encumbered by duration to accomplish experimentation, sensitivity to digestibility factor, overall energy consideration, availability of equipment, and cost. For these reasons, there has been continuous modifications of biological methods for protein evaluation to make them simpler and yet maintaining accuracy. For example, NPU experiments changed from use of whole carcass, through hind limb, to liver $[4,5,6]$. In similar vein, we have in the past five years developed in our laboratory speedy, economical and reproducible proximate technique to evaluate 'soluble protein equivalent's (spe) of BV and PER. Samples are drawn from the bloodstream for analysis to account for digestion, absorption, energy consideration, and possible protein losses in urine and faeces. Results obtained are independent of experimental animals employed. The experimental feeds provide sufficient protein and energy required for maintenance of tissue, and growth of the animal. The present study, therefore, reports this application on the comparative biological qualities of PBMK and a conventional animal feed of Morinda lucida leaves fed to goats for seven (7) weeks.

\subsection{Procurement and handling of raw materials}

\section{Materials And Methods}

Bush mango (Irvingia gabonensis) seeds, and (female) goats were purchased at Anyigba (Kogi State, Nigeria) central market while Morinda lucida leaves were plucked from shrubs within Anyigba and its environ.

The methodology of Arogba[7] was adopted to obtain processed BM kernels. Testa was retained. The dried kernels were ground manually into powdery form (grits). Similarly, the leaves of M. lucida were ovendried at $65^{\circ} \mathrm{C}$ until constant weight was achieved, cooled, and ground. 


\subsection{Experimental design}

The dried ground leaves of M. lucida were substituted at ordinal intervals of $25 \%$ with PBMK grits and fed to five young she-goats weighing 4.8 to $5.9 \mathrm{~kg}$, in fabricated cages, for 7 weeks. Water was provided adlibitum. The sixth animal which served as a reference, was sacrificed on the first day of the experiment (zero day). Over the period, physical weights of animals, liver, kidney, feeds, and faeces were taken. Soluble protein concentration equivalents (spe) in the blood, feeds, and faeces were determined by biuret method [8]. The blood samples $(2.5 \mathrm{ml}$ each) were freshly syringed on sacrificing the animals, and made up to $100 \mathrm{ml}$ with normal saline. Varied volumes $(0.2-1.0 \mathrm{ml})$ were withdrawn for use in the biuret test. Each determination was replicated twice. At the end of $7^{\text {th }}$ week, parameters measured were respectively 'normalised' with respect to the weight of the reference animal.

\subsection{Formulae}

$\mathrm{PER}_{(\text {spe })=}$ Weight gain $\mathrm{x}$ soluble protein factor / soluble protein intake

Where: Weight gain = grams of gain /normalised body weight of animal

Protein factor $=$ gram protein $/$ gram feed

Protein intake $\equiv$ feed consumed $\mathrm{x}$ protein factor

$\mathrm{BV}_{(s p e)=}$ Soluble protein retained / soluble protein absorbed

Where: Soluble protein absorbed $=$ soluble protein intake - soluble protein in faeces

\section{Results And Discussion}

Early researchers had experienced low food intake by animals in short periods of investigation and so, advocated long experimental period of between 4 and 8 weeks to allow for more consistent food consumption [9]. Indeed, previous experimentation with bucks fed for four weeks in our laboratory yielded no significant increase in weight gain. However, the seven weeks duration employed on this occasion has shown overall body weight gain in all animals of $5.1 \pm 0.4 \%$, but the order of \% gain in organ weights as reflected in kidney / liver was $68 / 56,11 / 57,9 / 19$ at $0 \%, 50 \%, 100 \%$ feed substitution respectively. It implied that weight gain by kidney decreased with increased PBMK level in feed. By its excretory function, vital nutrients such as soluble proteins and minerals could have been bio-unavailable through chelation with some phytochemicals. The earlier reports of Arogba et al [10] and Arogba[7,11,12,13] identified the presence of polyphenolic substances, particularly tannin, in the conventional mango (Mangifera indica) and I. gabonensis kernels (PBMK). Combined soaking and heat treatments during processing was further stated to appreciably reduce the anti-nutritional effects of such phytochemicals.

The residual concentrations of the phenolics in the processed kernels is implicated in the growth performance of experimental animals through their antioxidant activity [14], and could explain why liver growth was not adversely affected up to 50\% PBMK inclusion. The observation was further supported by results in Tables 1 and 2. There was progressive increment of soluble protein concentration in the blood as substitution with PBMK increased. The central role of the liver in integrated metabolism identified with the overall weight gain observed and the BVspe and PERspe, for which statistical separation of mean scores of the five feed formulations are shown.

The BVspe and PERspe values increased proportionally with the percentage PBMK in feed compared with the use of M. lucida leaves alone. The correlation coefficient, $r$, was calculated to be 0.9871 . Similar correlation has been reported between NPU and PER in a single experiment [9]. While the observations from this work and literature might not be surprising based on the relationship in definition between BV and NPU, the results obtained in this experiment validate the reliability of the technique employed. From the experimental data on BVspe and PERspe, the 50\% substituted PBMK feed described an optimum level, of statistical significance $(\mathrm{p}<0.05)$ in the array. It was therefore, recommended as the best animal feed in the formulations for physiological and economic reasons.

\section{Conclusion}

The study has described a sensitive and reproducible proximate technique for biological protein quality assays. A 50\% PBMK substitution in feed formulation promoted liver growth, overall body weight gain, and improved protein quality status of livestock. 
TABLE 1: PROTEIN EFFICIENCY RATIO (PERspe) of M. lucida leaf-PBMK formulations fed to goats for 7 weeks

\begin{tabular}{llllll}
\hline & & \multicolumn{3}{c}{ Feed formula } \\
Animal & 1 & 2 & 3 & 4 & 5 \\
\hline \% PBMK in feed & 0 & 25 & 50 & 75 & 100 \\
Soluble protein factor in feed (g/g) )A) & 0.275 & 0.301 & 0.325 & 0.373 & 0.399 \\
Total feed consumed (g) & 1758 & 1664 & 1564 & 1521 & 1505 \\
Total feed consumed per 'Normalized body Weight' $(\mathrm{g} / \mathrm{g})(\mathrm{B})$ & 0.285 & 0.269 & 0.252 & 0.245 & 0.242 \\
Soluble protein intake for 7 weeks (g/g) (C) & 0.078 & 0.081 & 0.082 & 0.091 & 0.097 \\
Weight gained (g) & 270 & 280 & 300 & 300 & 320 \\
Weight Gained Per Normalized Body Weight (g/g) (D) & 0.044 & 0.045 & 0.048 & 0.048 & 0.051 \\
Weight gained $_{(\text {spe })}(\mathrm{g} / \mathrm{g})(\mathrm{E})$ & 0.012 & 0.014 & 0.016 & 0.018 & 0.021 \\
PER $_{(\text {spe })}$ (se=0.001) (F) & & & & \\
\end{tabular}

Where:

(Means with different letters across a row differed significantly at $\mathrm{p}=0.05$ )

$$
\begin{aligned}
& \text { spe }=\text { soluble protein equivalent } \\
& \text { PER }=\text { protein Efficiency ratio } \\
& \mathrm{C}=\mathrm{A} \times \mathrm{B} \\
& \mathrm{E}=\mathrm{A} \times \mathrm{D} \\
& \mathrm{F}=\mathrm{E} / \mathrm{C} \\
& \text { se }=\text { Standard error }
\end{aligned}
$$

\begin{tabular}{|c|c|c|c|c|c|}
\hline \multirow[b]{2}{*}{ Animal } & \multicolumn{5}{|c|}{ Feed formula } \\
\hline & 1 & 2 & 3 & 4 & 5 \\
\hline$\%$ PBMK in feed & 0 & 25 & 50 & 75 & 100 \\
\hline Soluble protein in faeces g/normalized body wt (A) & 0.050 & 0.120 & 0.131 & 0.216 & 0.215 \\
\hline $\begin{array}{l}\text { Total weight of faeces in } 7 \text { weeks per normalized body weight }(\mathrm{g} / \mathrm{g}) \\
\text { (B) }\end{array}$ & 0.103 & 0.103 & 0.102 & 0.103 & 0.102 \\
\hline Total soluble protein in faeces g/g normalized body weight (C) & 0.0052 & 0.0124 & 0.0132 & 0.0222 & 0.0219 \\
\hline Soluble protein absorbed $(\mathrm{mg} / \mathrm{g})(\mathrm{F})$ & 73.00 & 68.60 & 68.80 & 68.80 & 75.10 \\
\hline Soluble protein retained in the blood $(\mathrm{mg} / \mathrm{g})(\mathrm{G})$ & 4.67 & 4.75 & 5.53 & 5.65 & 6.34 \\
\hline $\mathrm{BV}_{(\text {spe })}(\mathrm{se}=0.4)(\mathrm{H})$ & $6.4^{\mathrm{c}}$ & $6.9^{b}$ & $8.0^{\mathrm{a}}$ & $8.2^{\mathrm{a}}$ & $8.4^{\mathrm{a}}$ \\
\hline
\end{tabular}

TABLE 2: BIOLOGICAL VALUES (BVspe) of M. lucida leaf-PBMK formulations fed to goats for 7 weeks

(Means with different letters across a row differed significantly at $\mathrm{p}=0.05$ )

$\mathrm{BV}=$ Biological value

spe $=$ soluble protein equivalent

$\mathrm{C}=\mathrm{A} \times \mathrm{B}, \quad \mathrm{E}=\mathrm{D}-\mathrm{C}, \quad \mathrm{H}=\mathrm{G} \times 100 / \mathrm{F}$

\section{References}

[1] V. Arthur, and S. James, The Mechanism of body function: Seventh edition (London: Churchill Livingstone, 1998)

[2] P.E. Mc Donald, U.A. Edward, and C.A. Morgan, Animal Nutrition. Fifth edition (London: Longman, 1998).

[3] V.W. Rodwell, Biosynthesis of the nutritionally non-essential amino acids, in K.R. Murray, K.G. Daryl , A.M. Peter, and W.R. Victor (Ed.), Harper's Biochemistry: $25^{\text {th }}$ edition (New York: McGraw-Hill, 1998) 307-323.

[4] D.S. Miller, and A.E. Bender, The determination of net utilization of protein by a shortened method, Br. J. Nutr., 9, $1955,382-388$.

[5] P.A. Lachance, and G.A. Miller. Protein quality assessment in the rat: correlation between whole carcass and hind limb nitrogen concentration, Nutr. Rep. Int., 7, 1973, 25-32.

[6] A. Sotelo-Lopez, and B. Lucas-Florentino. Determination of net protein utilization using whole carcass, hind leg or liver of the rat and its relationship with protein efficiency ratio determination, J. Nutr., 108, 1978, 61-66.

[7] S.S. Arogba, Physical, chemical and functional properties of Nigerian Mango (Mangifera indica) kernel, J. Sc. Food Agric., 73, 1997, 321-328.

[8] D.T. Plummer, An introduction to practical biochemistry: Second edition (New York: McGraw-Hill, 1978).

[9] A.E. Bender, Relation between protein efficiency and net protein utilization, S0007114556000245a (10,1956, 135-143).

[10] S.S. Arogba, O.L. Ajiboye, I.A. Ugboko, and S.Y. Essienette, Properties of polyphenol oxidase in mango (M. indica) kernel, J. Sci. Food Agric, 77, 1998, $459-462$.

[11] S.S. Arogba, The effect of testa on the physico-chemical properties, browning index, and functional properties of wild mango ( $I$. gabonensis) kernel, Inter-World J. Sci. Techn., 1(1), 2001a, 159 - 167.

[12] S.S. Arogba, Moisture adsorption isotherm and the effects of brining and $\mathrm{pH}$ on the functional properties of wild mango (I. gabonensis) kernel, Inter-World J. Sci. Techn., 1(1), 2001b, 177 - 185.

[13] S.S. Arogba, Phenolics: A Class of Nature's Chemical Weapons of Self-Preservation. First Inaugural lecture delivered at Kogi State University, Anyigba, Nigeria, on Tuesday $26^{\text {th }}$ August 2008.

[14] S.S. Arogba, and A. Omede, Comparative antioxidant activity of processed mango (Mangifera indica) and bush mango (Irvingia gabonensis) kernels. Nigeria Food J., 30 (2), 2012, 17-21. 